\section{Oppdatert om kosthold}

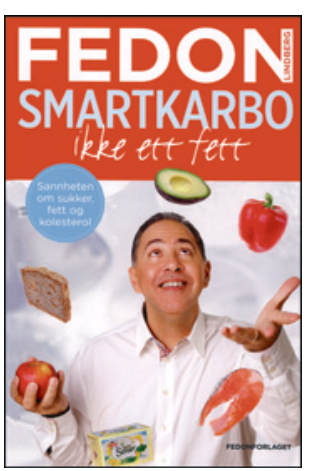

Fedon Alexander Lindberg

Smartkarbo - ikke ett fett

Sannheten om sukker, fett og kolesterol. 250 s, tab, ill. Oslo: Cappelen Damm, 2012. Pris NOK 349

ISBN 978-82-02-36948-4

Fedon Lindberg har siden 2001 skrevet 11 bøker om kosthold som til dels har solgt i store opplag. Flere av dem er oversatt til fremmede språk, blant annet kinesisk, og de er til sammen utgitt i 19 land. Hans første bokutgivelse var Naturlig slank med kost $i$ balanse. Denne boken var en av de første i Norge hvor søkelyset særlig var rettet mot hvor viktig det er å spise karbohydrater med lav glykemisk indeks.

Smartkarbo - ikke ett fett er på mange måter en utvidet og oppdatert versjon av den første boken. I denne nye boken har forfatteren vektlagt å gå gjennom ny kostholdsforskning som har tilkommet siden 2001. For eksempel er det et omfattende kapittel om hvilken rolle fett bør spille i et sunt kosthold. Lindberg fremholder at det trolig ikke er noen sammenheng mellom inntak av mettet fett og økt forekomst av hjerte- og karsykdom. Hans anbefalinger går i retning av å bytte ut en del av karbohydratinntaket, særlig inntaket av sukker og stivelsesholdige matvarer som brød, poteter, ris og pasta, med økt inntak av både mettet, enumettet og flerumettet fett av høy kvalitet. Han går også gjennom de ulike helsemessige effektene av de forskjellige typene fett på en oversiktlig og grei måte.

Lindberg presenterer også forskning som kaster nytt lys over kolesterol og den forenklede forestilling at et høyt totalkolesterol nødvendigvis er negativt for helsen. Han fremhever at kolesterol er en meget viktig komponent i hver eneste celle i kroppen. Forfatteren nevner også at kolesterol er en del av kroppens vedlikeholdsapparat som reparerer celleskade, og kanskje særlig de skadene som oppstår i arteriene under den inflammatoriske prosessen aterosklerose. Videre fremhever han at en del forskere derfor er av den oppfatning at kolesterol i seg selv derfor ikke er årsak til aterosklerose, men heller er et ledsagende fenomen i en reparasjonsprosess.

En gjennomgang av en del nye data, som tilsier at totalkolesterolverdien i blodet ofte har en meget begrenset diagnostisk verdi, er også tatt med. Han mener at det er et høyt nivå av HDL-kolesterol og et lavt nivå av LDL-kolesterol av typen «small dense LDL» og lave triglyserider som er helsemessig mest gunstig. Dette kan man oppnå med en diett som er rik på naturlige, sunne fettstoffer og karbohydrater med lav glykemisk indeks, mens en diett rik på raffinerte karbohydrater gir den motsatte effekten på blodlipidene.

Skal man forsøke seg på en karakteristikk av Lindbergs anbefalinger, kan man kanskje bruke begrepet «moderat lavkarbo». En fordeling av makronæringsstoffene med $40 \%$ av energien fra fett, $30 \%$ fra proteiner og $30 \%$ fra karbohydrater blir nevnt som et gunstig alternativ for mange.

Til slutt inneholder boken en rekke oppskrifter på sunn og næringsrik mat hvor fellesnevneren er at det er mat med lav glykemisk belastning.

Smartkarbo - ikke ett fett er velskrevet og beregnet på et allment publikum uten spesielle kunnskaper om kosthold, men også helsepersonell vil kunne ha nytte av å lese denne boken.

\section{God koke- og lærebok}

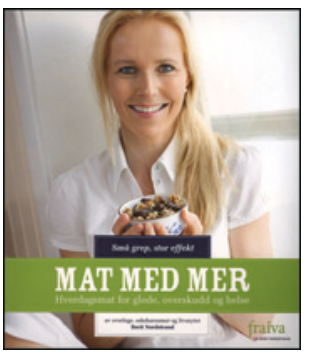

\section{Berit Nordstrand \\ Mat med mer}

Hverdagsmat for glede, overskudd og helse. 208 s, ill. Trondheim: Faiva, 2012. Pris NOK 259 ISBN 978-82-999043-0-8

Mat med mer er både en populær innføring i forskningsbasert ernæringslære og en bok om hvordan man med friske og gode, næringsrike matvarer på en ganske lett måte kan lage et sunt og smakfullt kosthold. Forfatteren er farmakolog med god innsikt i moderne ernæringsforskning. Hun populariserer kunnskapen om næringsstoffenes betydning og virkemåte på en enkel og pedagogisk grei måte.

Forfatteren gir råd om kosthold ved en rekke ganske vanlige tilstander eller sykdommer. Det er mat mot kreft, mat og diabetes, blodtrykksmat, treningsmat og betennelsesdempende mat. Forfatteren lover selvsagt ikke noen vidunderkur, for sykdommer og uhelse er forårsaket av mer enn bare et galt kosthold. Men rådene og veiledningen for matlaging og oppskrifter er gode. De er ganske enkle å få til i en travel hverdag, og de ser delikate ut. Bildene er vakkert komponert og bokstavelig talt appetittvekkende.

Det er egne kapitler om fisk og sjømat, egg og meieriprodukter, kjøtt, korn og hva slags fett man bør spise. Boken er både en kokebok og lærebok.

I en tid der befolkningen forvirres av ulike «ernæringseksperter», og avisene er fulle av mer eller mindre gale eller misforståtte råd om hva man bør spise, er det godt å få en bok skrevet av en lege, og som på en smakfull og pedagogisk måte forteller om hva riktig kosthold kan gi av helseeffekter og matglede til hele familien.

Dette er en bok som leger godt kan anbefale sine pasienter å kjøpe og bruke, både for å forebygge og behandle vanlige sykdomstilstander som har sin årsak i, eller sammenheng med, et galt kosthold.

\section{Kaare R. Norum}

Avdeling for ernæringsvitenskap Universitetet i Oslo 